\title{
LUT
}

Lappeenranta

University of Technology

\section{Digitalization of companies in international entrepreneurship and marketing}

Vadana Ioan-Iustin, Torkkeli Lasse, Kuivalainen Olli, Saarenketo Sami

This is a Author's accepted manuscript (AAM) version of a publication

published by Emerald

in International Marketing Review

DOI: $10.1108 / I M R-04-2018-0129$

Copyright of the original publication: (@) 2019, Emerald Publishing Limited

Please cite the publication as follows:

Vadana I., Torkkeli L., Kuivalainen O., Saarenketo S. (2019). Digitalization of companies in international entrepreneurship and marketing. International Marketing Review. DOI: 10.1108/ IMR-04-2018-0129 


\title{
Digitalization of companies in international entrepreneurship and marketing
}

\begin{abstract}
Purpose: Little research has been done on the emergence of companies that engage in increasingly digital entrepreneurship with digitalized value-chain activities. The extant literature provides an inconsistent picture of how value-chain digitalization affects companies' internationalization and international marketing, and gives no insights regarding the influence of the degree of value-chain digitalization on the level of internationalization.
\end{abstract}

Design/methodology/approach: This paper takes an explorative approach based on a literature review and uses a conceptual analysis and research framework to empirically classify digitalized/-ing companies.

Findings: This study finds ways to classify the internationalization of companies according to the degree of digitalization of their value chain. The more these companies use Internet hardware infrastructure and web and mobile software technologies, the better they can leverage their foreign assets, achieving a higher share of foreign sales with relatively limited foreign assets.

Research implications: The results enrich the literature on internationalization and international marketing and entrepreneurship to explain companies that are distinctly digitalized across their valuechain activities.

Practical implications: This research provides evidence for companies regarding digitalization of the value chain to facilitate entrepreneurial opportunities and offer rapid, efficient, affordable internationalization.

Originality/value: This research tackles a novel phenomenon by analyzing companies' value-chain digitalization in relation to their degree of internationalization and international marketing.

Keywords: digitalization, born digital, web, mobile technologies, value chain, internationalization, international marketing 


\section{INTRODUCTION}

The connected world and omnipresent technology have changed the rules for building brands, marketing strategies, and internationalization. While the Internet has enabled these transformations, the real drivers have been software and hardware technologies. Thanks to these changes, online customers/users expect simplicity (Brouthers, Geisser, \& Rothlauf, 2016), convenience, and relevance (Hänninen, Smedlund, \& Mitronen, 2017). This has given rise to digital entrepreneurship, which calls for new research approaches and explanations (Nambisan, 2017).

Research and online media indicate the emergence of a new type of companies (Bell \& Loane, 2010; Brouthers et al., 2016; Wentrup, 2016) that base their business development on the latest technologies and digitalization ${ }^{1}$ - the use of digital technologies to improve the business model, providing new revenue and value-producing opportunities (Hänninen et al., 2017; Nambisan, 2017). This study focuses on the literature in international marketing (IM) and international entrepreneurship (IE) to explore the types of digitalized/-ing companies ${ }^{2}$, how to measure the degree of digitalization (DOD) and degree of internationalization (DOI), and the consequences of the interplay between digitalization and internationalization. Digitalization implies coordination of value-chain activities using Internet infrastructure and web and mobile technologies, known as digital technologies (Acedo \& Jones, 2007; Brennen \& Kreiss, 2014; J. Li, Merenda, \& Venkatachalam, 2009). Broadly, however, value-chain digitalization

\footnotetext{
${ }^{1}$ Not to be confused with digitization, which is the process of converting any data into digits (i.e., $1 \mathrm{~s}$ and 0 s, in) (Brennen \& Kreiss, 2014).

${ }^{2}$ Not all companies are digitalized (some engage in digitalizing their activities later), and since this is a holistic term, it may confuse readers.
} 
describes the proportion of activities performed online (Kollmann \& Christofor, 2014). Digitalization affects a number of firms' functions and activities. For example, marketing, sales, and support are key in keeping or winning new customers, and improving business decisions based on algorithms crunching big data from digital technologies is proving essential (Hänninen et al., 2017). This could help companies serve their online customers around the world.

This article enriches the knowledge on internationalization, IM, and IE by exploring valuechain digitalization. Scholars (Bell \& Loane, 2010; Hamill, Tagg, Stevenson, \& Vescozi, 2010) have suggested the Internet creates easy paths to internationalization for companies and offers new ways of doing business, yet little research has examined the emergence of digitalized/-ing companies (Nambisan, 2017; Wentrup, 2016), beyond online promotion and sales. A conceptual literature review is carried out to answer the following questions: How are digitalized/-ing companies defined in the IE and IM literature? How can the DOD and DOI of these companies be measured? What are the consequences of interaction between digitalization and internationalization?

The existing literature is explored to define, measure, and classify the internationalization of digitalized companies based on their DOD. The next section presents the literature review, which begins with a general overview of digitalized/-ing companies and continues with details about the digitalization of the value chain and the internationalization dimension of these companies. Next results are presented, and the article concludes with a discussion and implications of this study. 


\section{LITERATURE REVIEW}

The literature suggests digitalization is more than a stimulant for companies; it is a changing context in which new technologies emerge and new capabilities are required (Nambisan, 2017; Reuber \& Fischer, 2011; Wentrup, 2016). Existing research has largely neglected digital technology's role in companies' internationalization pursuits, because this subject is novel and information is lacking. Even with the vast IM and entrepreneurship literature (Abrahamsson, 2016; Knight, 2000; Moen, Endresen, \& Gavlen, 2003; Quelch \& Klein, 1996; Webster, 1992), questions remain regarding the conceptualization of digitalized/-ing international companies, and about internationalization processes and challenges. These questions concern international behavior, business and marketing strategies (Bell \& Loane, 2010), the evolution of an onlineoffline balance (Wentrup, 2016), relationships between processes and resources, internationalization performance (Brouthers et al., 2016), business model particularities, and value-chain activities (Hernández \& Pedersen, 2017).

The literature was investigated to define sub-types of digitalized/-ing companies and find a basis for measuring their digitalization and internationalization. Relevant articles were identified by a three-step process. First, a search was conducted for the following keywords: "portals," "web," "Internet," “online," "web-based company," "platform," "Internet-enabled," “marketplace," “high-tech,” “technology companies,” “software,” "hardware,” “digital,” “digitalization," "e-marketing," "e-entrepreneurship," "e-business," "e-commerce," "mobile," “smartphone," "cyber-security," “cyberspace," "wireless," "information technology," "IT," or "ICT," combined with "internationalization," "international," "market entry modes," "foreign markets selection," "international performance," global," "foreign," "cross-national," "crosscultural," "export," or "import." These combinations were sought in titles and abstracts of 
articles published after 2000 in the top IM, IE, and IT journals, including the Journal of International Marketing, International Marketing Review, Journal of Marketing, Journal of Marketing Research, Journal of the Academy of Marketing Science, Journal of International Business Studies, Journal of World Business, Global Strategy Journal, Management and Organization Review, International Business Review, Journal of Business Venturing, Entrepreneurship Theory and Practice, Information and Management, Management Information Systems Quarterly, and Internet Research. The Web of Science and Science Direct databases were used to identify other relevant papers, as were the reference sections of the articles found through the search steps above. The search criteria yielded 94 sources.

Second, the five criteria of Rialp, Rialp, and Knight (2005) were adopted to refine the number of articles for review. Articles had to be published in English; in 2000-2018; conceptual, theoretical or empirical academic papers; closely related to the topic under discussion; and major works systematically listed as key references in other studies with a similar focus. The 2000-2018 time frame was selected because the concept of digitalization is young, and most related works have been published since 2000. It was assumed that any relevant research from the $20^{\text {th }}$ century is cited in the analyzed studies. These selection criteria yielded 45 sources.

In the last layer of selection, 35 articles were identified as covering the topic of internationalization of digitalized/-ing companies. The excluded papers are review articles or generally conceptual, focusing not on companies but on theoretical constructs. The review highlighted the lack of information and prior academic research available on this topic in the IM, IE, and information technology fields. 


\section{DESCRIPTIVE OVERVIEW AND CONCEPTUAL ANALYSIS}

All the analyzed sources focus on defining and investigating digitalization (see Tables 1 and 2).

Insert Table 1 about here

Insert Table 2 about here

Technology-based companies are characterized by their proprietary, innovative technologies, and might initially seem different from digitalized companies, characterized by using Internet networks and web and mobile technologies as key drivers of business development and rapid internationalization. However, technology-based companies also use the Internet to coordinate their value-chain activities and internationalization processes (Nambisan, 2017; Wentrup, 2016). Two dimensions-DOD and DOI-were used to outline these types of companies in comparison with less digital ones.

\subsection{DOI of digitalized/-ing companies}

As Table 2 illustrates, most of the measurements in the existing literature referring to digitalized/-ing companies' internationalization focus on linguistic and cultural similarities (Brouthers et al., 2016; Hennart, 2014; Kim, 2003; Mahnke \& Venzin, 2003; Reuber, 2016; Reuber \& Fischer, 2011), adaptation versus standardization (L. Li, Qian, \& Qian, 2012), the business model (Hänninen et al., 2017), internationalization speed (Hennart, 2014), online 
networks (Brouthers et al., 2016), market knowledge (Luo, Zhao, \& Du, 2005), or onlineoffline presence (Wentrup, 2016). These companies all generate value using the Internet; however, the literature suggests their internationalization processes may differ (Bell \& Loane, 2010; Brouthers et al., 2016; Nambisan, 2017; Wentrup, 2016).

Digitalization makes companies less physically and culturally constrained compared to traditional businesses (Luo et al., 2005). Nevertheless, the type of company analyzed by Wentrup (2016) follows a more near-market, gradual geographical pattern in its internationalization process, starting with the Nordic markets and expanding to nearby European markets. It has been argued that these companies prefer to enter international markets via controlled modes (e.g., subsidiaries; (Reuber, 2016; Sinkovics, Sinkovics, \& Ruey-Jer, 2013); sometimes digital companies cannot enter and be active in a market without an offline presence due to legal and market-specific requirements (Wentrup, 2016). There is likely a limit, therefore, on how long, or up to what size, a digital company can operate online without a physical presence.

Zhu and Qian (2015) argue that good digital information providers enter foreign markets with a well-developed Internet infrastructure as the availability and costs of such services influence success (Mahnke \& Venzin, 2003); see Table 2). Luo et al. (2005) indicate that a country in which a large percentage of the population uses the web and mobile technologies presents a more attractive market for e-commerce companies.

Competition is another driver of swift international expansion among online service providers (see Table 2; (Singh \& Kundu, 2002; Su, 2013). The first-mover advantage is often stressed 
(Kim, 2003; Knight \& Cavusgil, 1996; Oviatt \& McDougall, 1994; Wentrup, 2016; Yamin \& Sinkovics, 2006). Another important catalyst of digital companies' rapid internationalization is related to niche markets. Companies that sell niche products and services internationalize more quickly (Hennart, 2014; Nummela, Saarenketo, \& Puumalainen, 2004; Zucchella, Palamara, \& Denicolai, 2007). In international expansion, a company develops its domestic markets across international borders by integrating operations formerly carried out by intermediate product markets (Buckley \& Casson, 1976; Rugman, 1980). The literature has tried to capture the phenomenon of digitalized companies' internationalization, although the overview is still incomplete.

To the best of the authors' knowledge (see Table 3), research focuses much more on companies' outward internationalization (e.g., delivery, marketing and sales, support) of the value chain (Bell \& Loane, 2010; Brouthers et al., 2016; Crick \& Spence, 2005; L. Li et al., 2012; Wentrup, 2016; Zou, Chen, \& Ghauri, 2010) and less on inward internationalization activities (e.g., creating, producing; (Abrahamsson, 2016; Campos, del Palacio Aguirre, Parellada, \& de la Parra, 2009; Luo et al., 2005; Singh \& Kundu, 2002). Although marketing and sales are often core elements of early internationalization, this focus on outward internationalization offers only a partial image of these companies' functions and strategies.

Table 3. Papers focusing on inward versus outward internationalization regarding the value chain.

\begin{tabular}{l|l|l}
\hline \multicolumn{1}{c|}{ Inward internationalization } & \multicolumn{2}{|c}{ Outward internationalization } \\
\hline Mahnke \& Venzin, 2003 & Brouthers et al., 2016 & Stallkamp \& Schotter, 2019 \\
Luo et al., 2005 & Zhu \& Qian, 2015 & Javalgi, Todd, Johnston, \& Granot, 2012 \\
Campos et al., 2009 & Li et al., 2012 & Luo \& Bu, 2016 \\
Almor, Tarba, \& Margalit, 2014 & Mahnke \& Venzin, 2003 & Chen \& Kamal, 2016 \\
Singh \& Kundu, 2002 & Luo et al., 2005 & Hagsten \& Kotnik, 2017 \\
Ojala \& Tyrvainen, 2006 & Crick \& Spence, 2005 & Watson et al., 2018 \\
Luo \& Bu, 2016 & Bell \& Loane, 2010 & Shaheer \& Li, 2018 \\
Chen \& Kamal, 2016 & Almor, Tarba, \& Margalit, 2014 & Ojala, Evers, \& Rialp, 2018
\end{tabular}


Rezk, Srai, \& Williamson, 2016

Ojala, Evers, \& Rialp, 2018

Martinez-Noya et al., 2012
Kim, 2003

Hennart, 2014

Reuber, 2016

Wentrup, 2016

Mahadevan, 2000

Hänninen et al., 2017

Susarla, Anitesh, \& Whinston, 2003

Su, 2013

Ojala \& Tyrvainen, 2006

Styles \& Genua, 2008

Juho \& Mainela, 2009
Caniëls et al., 2015

Gabrielsson \& Gabrielsson, 2011

Ifinedo, 2011

The bolded references focus on both parts of the value-chain activities

\subsection{DOD of digitalized/-ing companies}

Studies use different terms like e-business (Brouthers et al., 2016), high-tech companies (Almor, Tarba, \& Margalit, 2014; Crick \& Spence, 2005; Juho \& Mainela, 2009; L. Li et al., 2012; Ojala \& Tyrvainen, 2006; Styles \& Genua, 2008; Su, 2013; Zhu \& Qian, 2015), digital information goods providers (Mahnke \& Venzin, 2003; Wentrup, 2016), new technology-based companies (Bell \& Loane, 2010; Campos et al., 2009; Mahadevan, 2000; Reuber, 2016), accidental internationalists (Hennart, 2014), or application service providers (Susarla, Anitesh, \& Whinston, 2003). Broadly, however, they view a digitalized company as any firm that provides its products and services to customers using the Internet and other technologies (Bell \& Loane, 2010; Nambisan, 2017; Wentrup, 2016). The extant literature suggests that Internet infrastructure and web and mobile technologies represent more than a catalyst for IE and IM; new phenomena are developing and new capabilities are needed in the international environment (Reuber, 2016). It is has become much easier to create links between most industries and customers based on web platforms enhanced by e-commerce solutions (Wentrup, 2016). 
Digitalized companies are commonly expected to sell digital products for which they do not require IM adaptation. The anticipated dynamic is the higher the DOD (Jean, Sinkovics, \& Kim, 2008), the lower the need for product and service adaptation. Yet the international performance of even digitalized companies depends on adaptation, enhanced by specific marketing strategies and communication languages and channels (Luo et al., 2005; Moen et al., 2003; Moen, Gavlen, \& Endresen, 2004; Reuber \& Fischer, 2011). Although differentiation and customization lead to a smaller market served at one time (Reuber, 2016), to be successful in foreign markets, digitalized companies' marketing strategies and capabilities also focus on adaptation and encouraging customers' involvement in improving their products (Knight, 2000; Luo et al., 2005; Moen, Koed Madsen, \& Aspelund, 2008).

Brouthers et al. (2016) suggest that digitalization of companies augments their value chain through servitization (Vandermerwe \& Rada, 1988), adding service capabilities and solutions to supplement their product offerings (Baines, Lightfoot, Benedettini, \& Kay, 2009; Neely, 2008; Vandermerwe \& Rada, 1988). For example, even online retailers requiring physical distribution of their products increasingly internationalize more rapidly than brick-and-mortar retailers do (Schu, Morschett, \& Swoboda, 2016).

Nambisan (2017) describes digital entrepreneurship through digital artifacts, platforms, and infrastructure. Digital artifacts present digital applications or online content as part of a new product (or service) offering a specific functionality or value to the end user. Digital platforms serve as a shared set of services and architecture that hosts complementary offerings. Digital infrastructure comprises systems that provide better communication, collaboration, or computing capabilities. If these characteristics are relied on to describe digitalized companies, 
however, important aspects captured by value-chain activities — which cover the full range of companies' activities to bring products or services from conception to end use and beyondmight be missed. Companies gain competitive advantage from how they configure the five main parts of the value chain (i.e., creating, producing, marketing and selling, delivering, and supporting products or services; (Porter \& Kramer, 2011); also see Table 4).

Table 4. Examples of digitalized value-chain activities.

\begin{tabular}{|l|l|l|l|l|}
\hline \multicolumn{1}{|c|}{ Creating } & \multicolumn{1}{|c|}{ Producing } & \multicolumn{1}{c|}{$\begin{array}{c}\text { Marketing and } \\
\text { selling }\end{array}$} & \multicolumn{1}{c|}{ Delivering } & \multicolumn{1}{c|}{ Supporting } \\
\hline $\begin{array}{l}\text { Research and } \\
\text { development } \\
\text { based on } \\
\text { technology and } \\
\text { behavioral data }\end{array}$ & $\begin{array}{l}\text { Online } \\
\text { platform/website } \\
\text { (web and/or } \\
\text { mobile) }\end{array}$ & $\begin{array}{l}\text { Online payment } \\
\text { system; } \\
\text { marketing based } \\
\text { on social media, } \\
\text { analytics }\end{array}$ & $\begin{array}{l}\text { Online } \\
\text { delivery/last-mile } \\
\text { delivery service }\end{array}$ & $\begin{array}{l}\text { Online customer } \\
\text { care }\end{array}$ \\
\hline
\end{tabular}

Source: Literature review papers $(\mathrm{n}=35)$ and example companies.

Already, web technologies have made product and service information ubiquitous; social media drives consumers to share, compare, and rate experiences; and mobile devices add a "wherever" dimension to the digital environment. To win over customers, companies must know them and their expectations, and must be able to reach customers with the right kind of interaction. Marketing based on social media and analytics is key to building that understanding — data to define and contextualize trends, to measure the effectiveness of activities and investments at key points in the consumer decision journey, and to understand how and why individuals move along those journeys (Bell \& Loane, 2010; Brouthers et al., 2016; Javalgi, Todd, Johnston, \& Granot, 2012; Kim, 2003; Luo et al., 2005; Mahnke \& Venzin, 2003; Singh \& Kundu, 2002).

Management literature uses the terms global value chain (Gereffi \& Fernandez-Stark, 2011; Hernández \& Pedersen, 2017) and global factory (Buckley, 2011; Buckley \& Ghauri, 2004) to 
describe the situation where some of a company's activities are located in other countries. This paper refers to the value chain as defined by Porter (1985). ${ }^{3}$ In the analyzed literature, the most frequent metrics for assessing the digitalization of value-chain activities relate to marketing, sales and support. Market performance plays an important role, but this neglects most parts of the value chain (see Table 3). Thus, too little is known about other modes and value-chain internationalization (Mudambi \& Zahra, 2007).

\section{RESEARCH FRAMEWORK}

Based on the literature review a conceptual research framework was used to classify digitalized/-ing companies based on the relationship between age of the company (young vs. mature), DOD (domestic vs. international) and DOI (high vs. low). Following Lowy and Hood (2004), the framework was built using a $2 \times 2$ matrix. In addition, classification was used as a tool to find the main patterns among these companies.

Classification was carried out using three dimensions (see Figure 1):

- Age of the company (Crick \& Spence, 2005; Hennart, 2014; Kim, 2003; Luo et al., 2005);

- DOD of its value chain, inward (Almor et al., 2014; Campos et al., 2009; Mahnke \& Venzin, 2003) and outward (Brouthers et al., 2016; Hänninen et al., 2017; Wentrup, 2016); and

\footnotetext{
3 "Value chain is a system of interdependent activities" (p. 48).
} 
- DOI of the online-offline geographical dispersion of its value-chain activities in foreign markets (Nambisan, 2017; Reuber \& Fischer, 2011; Sinkovics et al., 2013; Wentrup, 2016).

In Figure 1, the horizontal axis captures the time and internationalization dimension (age of the company; domestic/international); the vertical axis captures the DOD of the value-chain activities (high/low). Thus, enterprises in the first quadrant can be referred to as born-digital (BD) companies: companies in which most of the value chain is highly digitalized soon after inception. In general, they are characterized by their easier approach to accessing foreign markets compared to low-tech companies - a consequence that makes it necessary to shed light on the IM and entrepreneurship activities of BD companies as well.

The digitalized value-chain activities that represent DOD—-defined by "high digitalization" differ according to the core product's nature. To avoid considering all companies founded in the Internet era as $\mathrm{BD}$, based only (for example) on the use of email as an Internet communication tool, it is assumed that BD companies should have highly digitalized most $\operatorname{parts}^{4}$ of their value chain straight from their inception (Figure 1).

The second quadrant in Figure 1 includes BD companies and those with a highly digitalized value chain that experienced the transformation later in time ("mature digital" companies). The third and fourth quadrants comprise companies with a low-digitalized value chain, defined by age as "young low digital" and "mature low digital," respectively. ${ }^{5}$

\footnotetext{
${ }^{4}$ This is an arbitrary criterion, but it helps distinguish between software companies with digital products and those with tangible products.

${ }^{5}$ The authors thank an anonymous reviewer for the suggestion to add terms denoting firms that are not BD.
} 
Figure 1. Classification of digitalized/-ing companies based on degree of digitalization (DOD) and degree of internationalization (DOI). BD: born digital.

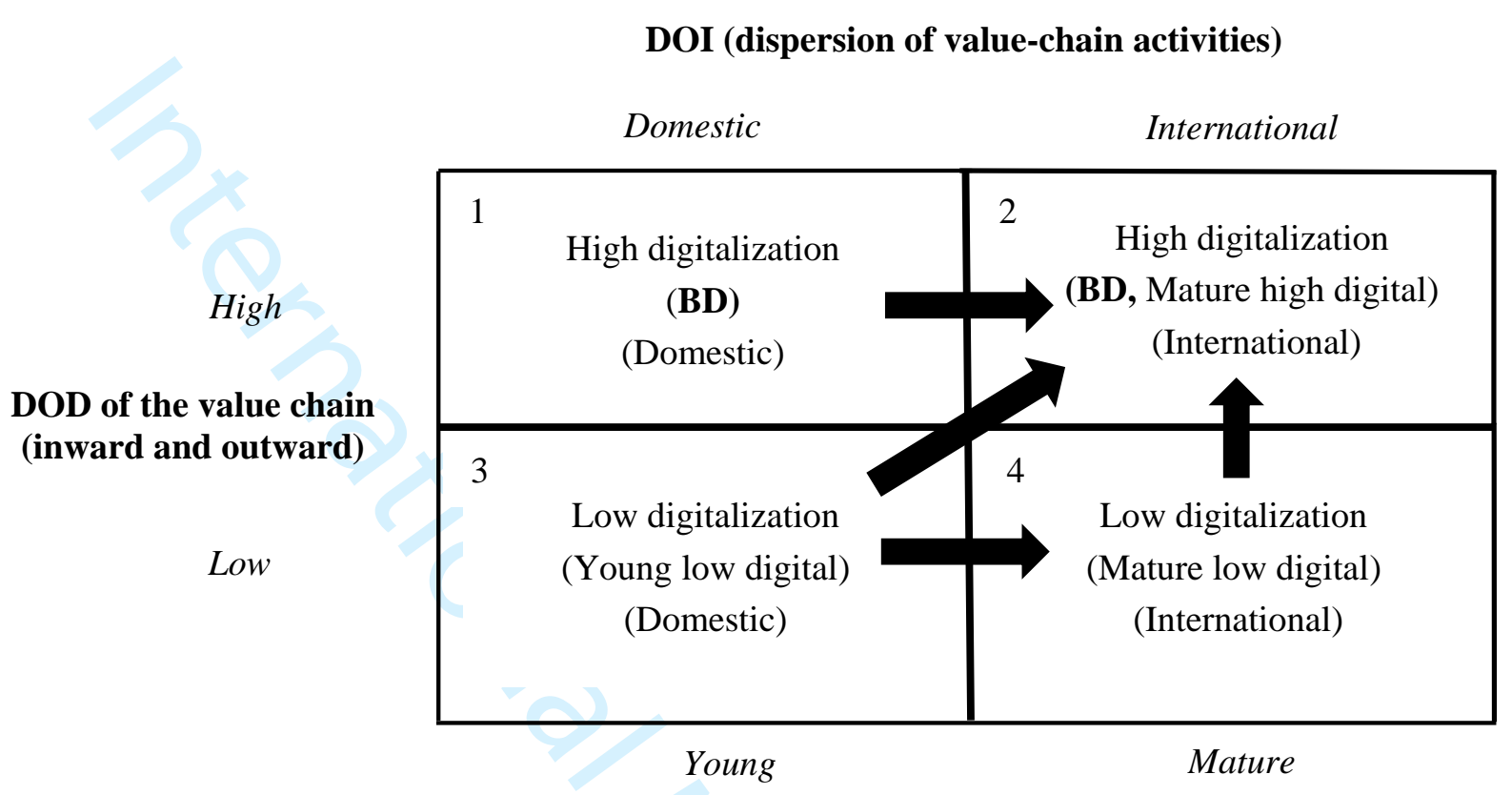

Age of the company

After analyzing metrics in the existing literature, the internationalization perspective was measured in terms of dispersion of value-chain activities online (e.g., development, website translation/localization, online sales/support) and offline (e.g., delivery, global offices, on-site support; (Reuber, 2016; Sinkovics et al., 2013; Wentrup, 2016). Moreover, to measure valuechain digitalization, the inward (Almor et al., 2014; Campos et al., 2009; Mahnke \& Venzin, 2003) and outward (Brouthers et al., 2016; Hänninen et al., 2017; Wentrup, 2016) metrics from the literature were used.

This framework identifies specific types of companies in each quadrant of the matrix. In time, by updating their DOI and DOD, companies can change quadrants. In the first quadrant of Figure 1, not all companies are $\mathrm{BD}$ and not all $\mathrm{BD}$ companies are international; however, the focus is on those companies that follow an international path, toward the second quadrant. BD 
companies can become internationally operating high-digital companies when they move from quadrant 1 to quadrant 2; "young low digitals" become internationally operating low-digital companies when they move from quadrant 3 to quadrant 4, but they can also become "mature high digital" by moving, over time, to quadrant 2 .

The main differences between types of companies in Figure 1 are the DOD of the value chain (high vs. low), and the DOI-the online-offline geographical dispersion of activities, domestically and internationally. The horizontal axis measures the number of countries in which these companies have value-chain activities, offline (i.e., with offices) and online, based on the number of localized websites or domains in a country's official language. The first two quadrants therefore comprise BD companies, and the other two represent companies in different stages of digitalization, with domestic or international activities. The arrows emphasize the processes of digitalization and internationalization of the company types in quadrants 1,3 , and 4.

An absolute online presence can be surmised at one extreme point, meaning all value-chain activities are run on Internet infrastructure and coordinated by web and mobile technologies. Companies in this category operate almost entirely in a virtual setting. At the other extreme, a purely offline presence means only physical resources are present (Wentrup, 2016). In practice, degrees of online and offline presence may vary over time (Sinkovics et al., 2013). Clear evidence of a balance between online and offline activities is provided by the type of resource involved in the two domains (Wentrup, 2016). In terms of selling and marketing value-chain activity, online entry may be nearly instantaneous if a product or service is available online in a specific market. While an offline entry may be more gradual and time-consuming, the 
necessity of entry seems to increase with time (Wentrup, 2016). The efficiency of the internationalization strategy allows such ventures to "bootstrap" into international markets.

Five companies-Avito.ru, Farfetch, HelvetiBox, HelloFresh, and IKEA-were chosen to illustrate the different types of companies distinguished by the number of value-chain activities enabled by web and mobile technologies and the number of countries in which any value-chain activities occur.

As Figure 2 shows, more digitalization increases the dispersion of geographic activities (online and offline) around the world. Not all BD companies, however, operate internationally. The companies in the first two quadrants display similar digitalization. The most important difference between them is the number of activities in foreign markets. When digitalization is

Figure 2. Classification of digitalized/-ing companies based on degree of digitalization (DOD) and degree of internationalization (DOI).

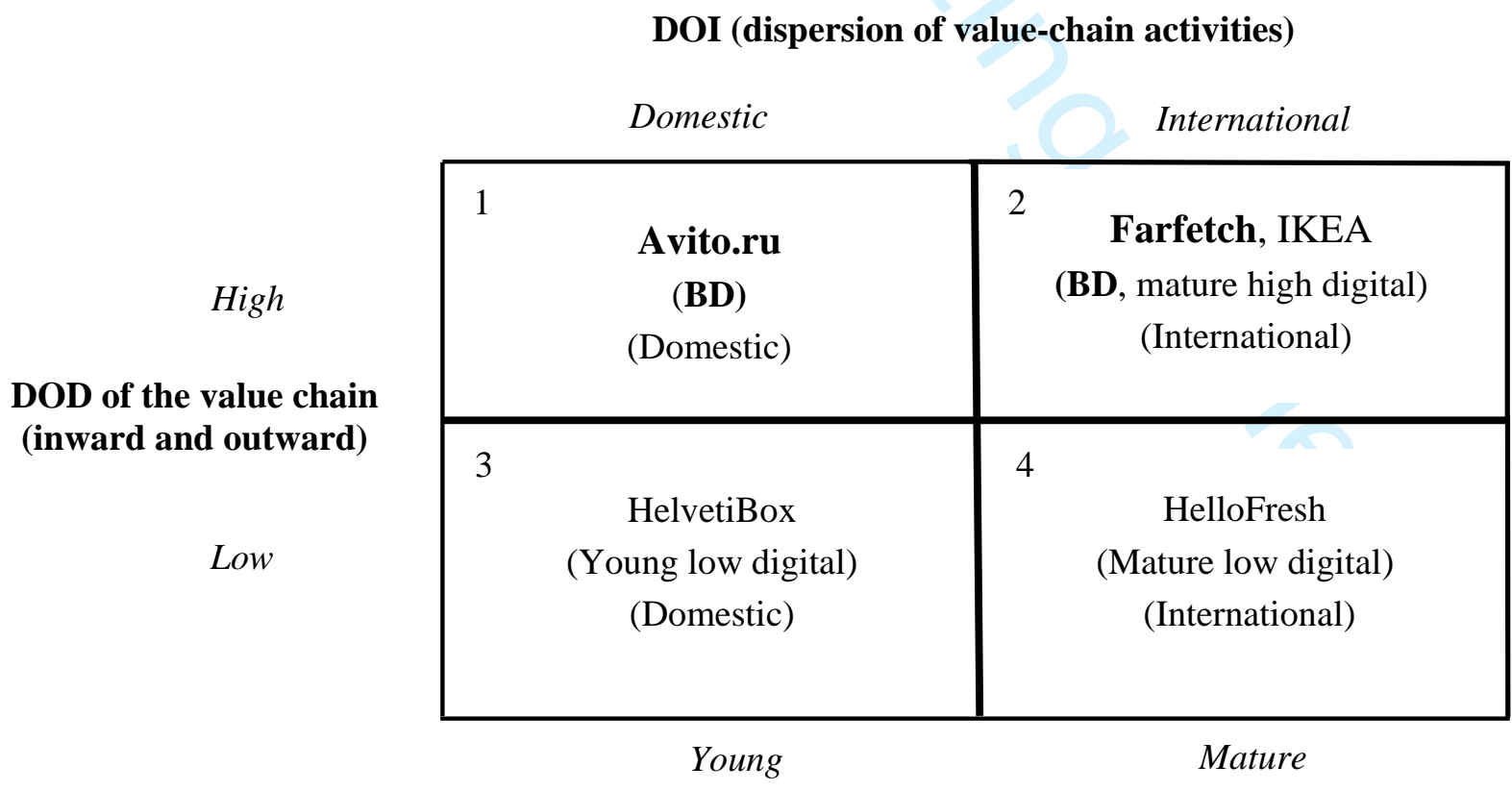

Age of the company 
used for coordinating value-chain activities, BD companies can expand faster internationally than those with a less-digitalized value chain.

\begin{abstract}
Avito.ru, an online classified ad platform, is a BD company having a highly digital value chain since its inception. It is a technology company providing an e-commerce platform (i.e., core business) with classified ads and online shops. Its platforms include an online payment system, and it uses online marketing campaigns based on data generated by its users. Most of its services can be delivered from headquarters.
\end{abstract}

Farfetch is a British international fashion marketplace that uses an online e-commerce platform to sell clothes made by designers from around the world. Rather than having a warehouse, Farfetch acts as an online matchmaker between customers and brands. Brands can create an eshop on Farfetch's main site or use the company's technology to power their online store. It gives access to brands from 25 countries and has customers in over 170 markets. Using social media platforms, analytics scripts, and mobile apps, Farfetch collects and analyzes user information to create an individualized marketing strategy for each customer, enabling prediction of each customer's future demands. This ability allows the company to send automatically optimized email and online campaigns to each user. The company's business strategy is fueled by its customer service, on-time delivery system, and advantageous returns and refunds policy.

HelloFresh is a provider of fresh food at home. It has headquarters in Berlin and operations in 11 markets across three continents. HelloFresh generates revenue from the sale of recipe boxes, which varies depending on the frequency of meals and number of people per meal. Each week, 
customers choose their meal plan and select a delivery day. Other than the website (i.e., marketing, sales and support), this company performs value-chain activities (i.e., supplier partnerships, logistics, storage, delivery) offline. HelloFresh has a web-based business model (i.e., an online platform), but exemplifies a mature low-digital company, with international activities since 2012 .

HelvetiBox is a service founded in 2015 in Cordast, Switzerland. Customers use the HelvetiBox website to order 5-8 Swiss-made specialty foods per month. Despite the website (i.e., marketing, sales and support), most value-chain activities (e.g., logistics, supplier partnerships, storage, delivery) are conducted offline. This is a clear example of a young web-based company (i.e., an online platform), with a low-digitalized value chain and domestic activities, but with the potential to go international and increase the digitalization of its value chain.

IKEA is one of the biggest furniture companies in the world, founded in Älmhult, Sweden, in 1943. As its internationalization process took more time and resources, IKEA adopted digitalization of the value chain more than a decade ago, enhancing their initial brick-andmortar business model. This example of a mature high-digital company combines online (eshop) with offline (store) into an omnichannel concept covering a large scale of customers.

Depending on the industry, tangible foreign assets in international markets are still used, but are often defined by business offices or data centers (UNCTAD, 2017), needed more for policy issues or customer support. Overall, the firm cases show that early digitalization of the value chain, translated into a stronger online presence, followed by a gradual increase in resources dedicated to offline presence, may present one solution for BD companies' sustainable growth. 


\section{DISCUSSION}

This exploratory study focused on testing metrics selected from the literature review, and the proposed research frameworks. Few studies have attempted to analyze companies from these perspectives, and the IE and IM literature on digitalization is still in its nascent stages. This paper reviewed the current concepts describing different types of digitalized/-ing enterprises (Nambisan, 2017; Wentrup, 2016), mostly focusing on BD. Suitable metrics were identified for developing an empirical classification of low- and high-digital companies by analyzing several theoretical research models in the existing literature. Developing standard definitions, conceptualizations, and metrics increases research clarity, as well as the comparability of companies across regions, countries, and specific industries. This work was carried out to close some of the gaps in the literature.

Digitalization forms distinct types of companies (international or not) for many reasons, but especially due to the business model. Companies that are highly digitalized from their inception, defined here as BD, using a high DOD of the value chain, intensively coordinate their activities using Internet infrastructure and web and mobile technologies. Both the literature review and the empirical cases suggest the decision center is generally the home country, and the geographical and psychic distance between the foreign market and home country is sometimes critical for the company's success (e.g. in line with all analyzed cases, and in) (Luo et al., 2005; Rissanen, Ermolaeva, Ali, Torkkeli, \& Saarenketo, 2019; Singh \& Kundu, 2002; Wentrup, 2016; Zhu \& Qian, 2015). These companies are distinguished from those whose highly digitalized value chain developed later in time (mature digital companies), and by young low digitals and mature low digitals, that have not yet experienced a digital transformation. 


\begin{abstract}
Research suggests some internationally operating BD companies may represent a subset of born-global companies (i.e., companies that internationalize early and rapidly); based on Hennart's (2014) work, one can expect BD companies' behavior to be determined largely by their business models, which generate revenues from an early stage (Ojala \& Tyrvainen, 2006; $\mathrm{Su}, 2013$ ). These companies are generally perceived as rapidly internationalizing (Bell \& Loane, 2010), because of the high DOD of their value chain from the beginning (Brouthers et al., 2016; Wentrup, 2016). This could be a topic for further empirical research.
\end{abstract}

\title{
5.1 Theoretical implications
}

This study explored the digitalization phenomenon, analyzing several metrics in the extant literature. It concludes by recommending a framework that relies on the relevance of digitalized value-chain activities and IM, using both online and offline dimensions of the geographical distribution of value-chain activities, to present a conceptual analysis of the characteristics and metrics of companies' digitalization, mostly focusing on BD. Most metrics found in the analyzed literature do not fit the particularities of digitalized/-ing companies; therefore, a new set of metrics and a model are proposed to classify them.

Most papers included in the literature review use web-based technologies to measure the digitalization of value-chain activities (Bell \& Loane, 2010; Brouthers et al., 2016; Hänninen et al., 2017; Hennart, 2014; Kim, 2003; Luo et al., 2005; Mahnke \& Venzin, 2003; Reuber, 2016; Wentrup, 2016). Thus, BD companies are service or product companies in which most of the value chain is highly digitalized; further, they either experienced that transformation soon after inception or did not need to transform. Mature digital companies, in contrast, entered this 
process long after inception and have a brick-and-mortar business strategy, combining offline with online activities. Still others (mature low-digital and young low-digital companies) have not finished or have only begun digital transformation; their value-chain activities rely more on offline functions, and their internationalization process is slower because their speed of learning is lower (Autio, Sapienza, \& Almeida, 2000; Hennart, 2014; Sinkovics et al., 2013).

The digitalized activities that show DOD differ mainly in relation to product nature. If the product is tangible, a higher DOD is reached when production and distribution are coordinated with Internet technologies. Servitization also helps tangible products attain a high DOD. Baines et al. (2009) and Neely (2008) argue servitization offers significant potential value, providing solutions for companies to update their value chain and reap greater benefits by creating more complex and refined products and services.

Digitalized companies must have most parts of the value chain digitalized, or at least enhanced or coordinated by Internet infrastructure and web and mobile technologies. Internationalization occurs largely because of the digital nature of the value-chain activities. The framework indicates that empirical investigators interested in digitalized companies, especially BD companies, will find larger sample sizes in industries with a highly developed Internet infrastructure (Mahadevan, 2000; Susarla et al., 2003; Wentrup, 2016). The framework also distinguishes companies by domestic versus international activity; however, empirical research is needed to better understand the correlation between the value chain and internationalization. Digitalization is presumed to increase internationalization. There are IM-related issues (e.g., barriers of entry) based on liability of foreignness and newness (Hymer, 1976; Zaheer, 2002), and digitalized companies must overcome numerous marketing challenges to motivate 
customers to find, trust, and purchase their offerings (Rangan \& Adner, 2001; Yamin \& Sinkovics, 2006).

Furthermore, the international performance of digitalized companies depends on product or service adaptation (Luo et al., 2005; Moen et al., 2003; Moen et al., 2004; Reuber \& Fischer, 2011) correlated with a marketing strategy focused on customers' or users' involvement (Knight, 2000; Luo et al., 2005; Moen et al., 2008). These companies often offer their products or services first for a niche market; they adapt quickly to control that market, and after may become mainstream. Digitalization of outward value-chain activities like marketing, sales and support tends to increase the international performance of inward activities, especially improving R\&D by driving innovation based on customers' input and behavioral data (Almor et al., 2014; Crick \& Spence, 2005; Hennart, 2014; Luo et al., 2005; Mahnke \& Venzin, 2003).

This study employs a holistic framework to clarify the discussion on digitalization in the context of IE and IM. It integrates the new concept of $\mathrm{BD}$, which explains the digitalization phenomenon through an innovative perspective, analyzing the digital value-chain activities correlated with internationalization across two dimensions - online and offline. According to the literature, the interplay between online and offline internationalization and DOD increases knowledge of foreign markets and users, meaning digitalized companies grow more rapidly internationally, extending the dispersion of value-chain activities (Autio et al., 2000; Brouthers et al., 2016; Nambisan, 2017; Wentrup, 2016; Yamin \& Sinkovics, 2006). Going forward, this classification will help in developing new theories by analyzing digitalized/-ing companies' internationalization patterns and strategies. 


\subsection{Managerial and policy implications}

The managerial implications of this research relate to informing entrepreneurs and managers about solutions employing Internet hardware infrastructure and web and mobile software technologies in their companies' IM strategies; they can use these strategies to internationalize. Integrating the strategy of digitalizing value-chain activities into marketing and business objectives could help companies expand their traditional boundaries and internationalize, evolving into an interwoven two-tier market (i.e., physical and virtual). The more these companies use web and mobile technologies, the better they can leverage assets in foreign markets (UNCTAD, 2017).

Focusing on digitalization of inward and outward processes and value-chain activities, managers can identify IM strategies to boost innovation and increase firm performance (Lee, Lee, \& Pennings, 2001; Luo et al., 2005; Mahnke \& Venzin, 2003; Su, 2013; Susarla et al., 2003). With higher digitalization of value chains, companies can track users and identify relevant value drivers to invest in product or service upgrading. Greater digitalization will virtually decrease the distance between companies and customers (Kollmann \& Christofor, 2014). Internationalization through these processes will give companies access to different types of experiential knowledge from different sources, generating a positive effect on turnover.

Based on the model of BD or even mature digital companies, managers can consider the longterm effects of failing to commit sufficient resources to their offline presence in markets with a high psychic distance early in the internationalization process. The rapport between online and offline entry should be considered carefully by both types of companies since online consumer preferences often differ between geographical markets. Failing to do so may affect the 
company's internationalization speed. Internationally expanding firms may want to keep their marketing strategy (e.g., branding) in-house because customer learning facilitated by branding is essential to prevail in foreign markets (Mahnke \& Venzin, 2003).

The internationalization success of digitalized companies relates to the value generated by providing an online platform, organizing the marketing strategy for user adoption, and managing users' cross-relationships. Business models built on online platforms redefine the basic logic of most industries (Bell \& Loane, 2010; Brouthers et al., 2016; Hänninen et al., 2017; Nambisan, 2017; Wentrup, 2016). Companies may mediate deals between buyers and suppliers rather than approaching the whole supply and logistics chain independently. Business model innovation determines the success of user adoption and, ultimately, internationalization; this can help managers adapt to business models of digitalized companies across a wide range of industries. In addition, policymakers must consider that the penetration of leading digitalized companies into their country will energize the digitalization of broader economic activities.

Low-digitalized companies seem to have better opportunities when shifting to a fully digitalized value chain. The present findings may underline the importance of digitalization of all valuechain activities (inward and outward). A better understanding of digitalization opportunities in the upstream part of the value chain allows shaping the IM strategy accordingly, improving the overall prospects of internationalization.

\section{LIMITATIONS AND FUTURE RESEARCH}


This study has several limitations. First, it focused on new theoretical conceptualizations and empirical findings regarding the internationalization of digitalized companies. Considering the novelty of the research topic, the available information is limited. As is the case in international new venture and born-global studies, studies on digitalization focus too much on high-tech industries (Andersson, Evers, \& Kuivalainen, 2014), and little is known about other industries' digitalization efforts. Another potential limitation could be the digitalization metric based on the company's value chain. Most activities are Internet related, and it can be difficult to track where in their value chains companies have their activities. Furthermore, the internationalization metrics proposed in this study must be tested and verified, and the lack of variance of DOI may be an important limitation.

Future research should explore the corresponding themes. For instance, the BD phenomenon has been analyzed thoroughly based on the study of large companies; however, other perspectives are needed on how the value-chain structure, digitalization, country of origin, and dynamism of the industry may influence the evolution of BD companies. There may eventually be other typologies of BD companies or subcategories based on different criteria.

It would be useful to explore issues such as the role of value-chain digitalization in internationalization; the impact of high digitalization of value-chain activities on internationalization strategy and international performance; or the speed of learning of BD companies and its impact on the relation between internationalization process/strategy and international performance. 
The internationalization process includes multiple steps. In general, companies' inwardoutward activities are initially related to geography; they begin with regional expansion, balancing the resources invested in their online and offline presence to expand to new international markets. There may be a significant difference between an information and communication technology (ICT)-based firm and an ICT-intensive one. A more thorough investigation of the differences between product and service companies could strengthen the validity of this paper.

Digital technologies foreshadow the next era in IM and IE. The traditional means of following marketing and entrepreneurial opportunities will be increasingly questioned and reworked. BD companies represent the beginning of this new era in how internationalization will be achieved. 


\section{REFERENCES}

Abrahamsson, J. (2016). Beyond Going Global - Essays on Business Development of International New Ventures Past Early Internationalization. (Doctoral dissertation), Umeå University, Sweden. Retrieved from Available at: http://urn:nbn:se:umu:diva-125469

Acedo, F., \& Jones, M. (2007). Speed of internationalization and entrepreneurial cognition: Insights and a comparison between international new ventures, exporters and domestic firms. Journal of World Business, 42(3), 236-252.

Almor, T., Tarba, S. Y., \& Margalit, A. (2014). Maturing, Technology-Based, Born-Global Companies: Surviving Through Mergers and Acquisitions. Management International Review, 54(4), 421444.

Andersson, S., Evers, N., \& Kuivalainen, O. (2014). International new ventures: rapid internationalization across different industry contexts. European Business Review, 26(5), 390405.

Autio, E., Sapienza, H. J., \& Almeida, J. G. (2000). Effects of age at entry, knowledge intensity, and imitability on international growth. Academy of Management Journal, 43, 909-924.

Baines, T. S., Lightfoot, H. W., Benedettini, O., \& Kay, J. M. (2009). The servitization of manufacturing: A review of literature and reflection on future challenges. ournal of Manufacturing Technology Management, 20(5), 547-567.

Bell, J., \& Loane, S. (2010). 'New-wave' global firms: Web 2.0 and SME internationalisation. Journal of Marketing Management, 26(3-4), 213-229.

Brennen, S., \& Kreiss, D. (2014). Digitalization and Digitization. Retrieved from Culture Digitally website: http://culturedigitally.org/2014/09/digitalization-and-digitization/

Brouthers, K. D., Geisser, K. D., \& Rothlauf, F. (2016). Explaining the internationalization of ibusiness firms. Journal of International Business Studies, 47(5), 513-534.

Buckley, P. J. (2011). International integration and coordination inthe global factory. Management International Review, 51(2), 269-283.

Buckley, P. J., \& Casson, M. (1976). The future of the multinational enterprise. London: Macmillan.

Buckley, P. J., \& Ghauri, P. N. (2004). Globalisation, economic geography and the strategy of multinational enterprises. Journal of International Business Studies, 35(2), 81-98.

Campos, H. M., del Palacio Aguirre, I., Parellada, F. S., \& de la Parra, J. P. N. (2009). Technology Strategy and New Technology Based Firms. Journal of Technology Management \& Innovation, $4(4), 42-52$.

Caniëls, M. C. J., Lenaerts, H. K. L., \& Gelderman, C. J. (2015). Explaining the internet usage of SMEs: The impact of market orientation, behavioural norms, motivation and technology acceptance. Internet Research, 25(3), 358-377.

Chen, W., \& Kamal, F. (2016). The impact of information and communication technology adoption on multinational firm boundary decisions. Journal of International Business Studies, 47(5), 563576.

Crick, D., \& Spence, M. (2005). The Internationalisation of 'High Performing' UK High-Tech SMEs: A Study of Planned and Unplanned Strategies. International Business Review, 14(2), 167-185.

Gabrielsson, M., \& Gabrielsson, P. (2011). Internet-based sales channel strategies of born global firms. International Business Review, 20(1), 88-99.

Gereffi, G., \& Fernandez-Stark, K. (2011). Global Value Chain Analysis: A Primer. North Carolina, USA: Duke University.

Hagsten, E., \& Kotnik, P. (2017). ICT as facilitator of internationalisation in smalland medium-sized firms. Small Business Economics, 48(2), 431-446.

Hamill, J., Tagg, S., Stevenson, A., \& Vescozi, T. (2010). Editorial. Journal of Marketing Management, 26(3-4), 181-186.

Hänninen, M., Smedlund, A., \& Mitronen, L. (2017). Digitalization in retailing: multi-sided platforms as drivers of industry transformation. Baltic Journal of Management, 13(2), 152-168.

Hennart, J.-F. (2014). The Accidental Internationalists: A Theory of Born Globals. Entrepreneurship Theory and Practice, 38(1), 117-135. 
Hernández, V., \& Pedersen, T. (2017). Global value chain configuration: A review and research agenda. Business Research Quarterly, 61, 1-14.

Hymer, S. (1976). The international operations of national firms: A study of direct foreign investment. (MIT PhD dissertation, 1960), Cambridge, MA.

Ifinedo, P. (2011). Internet/e-business technologies acceptance in Canada's SMEs: an exploratory investigation. Internet Research, 21(3), 255-281.

Javalgi, R. R. G., Todd, P. R., Johnston, W. J., \& Granot, E. (2012). Entrepreneurship, muddling through, and Indian Internet-enabled SMEs. Journal of Business Research, 65(6), 740-744.

Jean, R.-J. B., Sinkovics, R., \& Kim, D. (2008). Information technology and organizational performance within international business to business relationships: A review and an integrated conceptual framework. International Marketing Review, 25(5), 563-583.

Juho, A., \& Mainela, T. (2009). External facilitation in the internationalization of high-tech firms. In J. Larimo \& T. Vissak (Eds.), Research on Knowledge, Innovation and InternationalizationProgress in International Business Research (Vol. 4, pp. 185 - 204): Emerald Group Publishing Limited.

Kim, D. (2003). The internationalization of US Internet portals: Does it fit the process model of internationalization? Marketing Intelligence \& Planning, 21(1), 23-36.

Knight, G. (2000). Entrepreneurship and Marketing Strategy: The SME Under Glohalization. Journal of Intemational Marketing, 8(2), 12-32.

Knight, G., \& Cavusgil, S. T. (1996). The born global firm: A challenge to traditional internationalization theory. Advances in International Marketing, 8, 11-26.

Kollmann, T., \& Christofor, J. (2014). International entrepreneurship in the network economy: Internationalization propensity and the role of entrepreneurial orientation. Journal of International Entrepreneurship, 12(1), 43-66.

Lee, C., Lee, K., \& Pennings, J. M. (2001). Internal capabilities, external networks, and performance: a study on technology-based ventures. Strategic Management Journal, 22(6-7), 615-640.

Li, J., Merenda, M., \& Venkatachalam, A. R. (2009). Business Process Digitalization and New Product Development: An Empirical Study of Small and Medium-Sized Manufacturers. International Journal of E-Business Research, 5(1).

Li, L., Qian, G., \& Qian, Z. (2012). The performance of small and medium-sized technology-based enterprises: Do product diversity and international diversity matter? International Business Review, 21(5), 941-956.

Lowy, A., \& Hood, P. (2004). The Power of the 2x2 Matrix: Using $2 \times 2$ Thinking to Solve Business Problem and Make Better Decisions: Jossey-Bass.

Luo, Y., \& Bu, J. (2016). How valuable is information and communication technology? A study of emerging economy enterprises. Journal of World Business, 51(2), 200-211.

Luo, Y., Zhao, J. H., \& Du, J. (2005). The internationalization speed of e-commerce companies: an empirical analysis. International Marketing Review, 22(6), 693-709.

Mahadevan, B. (2000). Business models for Internet-based E-commerce: An anatomy. California Management Review, 42(4), 55-69.

Mahnke, V., \& Venzin, M. (2003). The Internationalization Process of Digital Information Good Providers. Management International Review, 43(1), 115-142.

Martinez-Noya, A., Garcia-Canal, E., \& Guillen, M. F. (2012). International R\&D service outsourcing by technology-intensive firms: Whether and where? Journal of International Management, 18(1), 18-37.

Moen, Ø., Endresen, I., \& Gavlen, M. (2003). Use of the Internet in International Marketing: A Case Study of Small Computer Software Firms. Journal of International Marketing, 11(4), 129-149.

Moen, Ø., Gavlen, M., \& Endresen, I. (2004). Internationalization of small, computer software firms: Entry forms and market selection. European Journal of Marketing, 38(9-10), 1236-1251.

Moen, Ø., Koed Madsen, T., \& Aspelund, A. (2008). The importance of the internet in international business-to-business markets. International Marketing Review, 25(5), 487-503.

Mudambi, R., \& Zahra, S. (2007). The survival of international new ventures. Journal of International Business Studies, 38, 333-352.

Nambisan, S. (2017). Digital Entrepreneurship: Toward a Digital Technology Perspective of Entrepreneurship. Entrepreneurship Theory and Practice, 41(6), 1029-1055. 
Neely, A. (2008). Exploring the financial consequences of the servitization of manufacturing. Operations Management Research, 1(2), 103-118.

Nummela, N., Saarenketo, S., \& Puumalainen, K. (2004). Rapidly with a rifle or more slowly with a shotgun? Searching the company boundaries of internationalizing ICT firms. Journal of International Entrepreneurship, 2(4), 275-288.

Ojala, A., Evers, N., \& Rialp, A. (2018). Extending the international new venture phenomenon to digital platform providers: a longitudinal case study. Journal of World Business, 53(5), 725-739.

Ojala, A., \& Tyrvainen, P. (2006). Business models and market entry mode choice of small software firms. Journal of International Entrepreneurship, 4(2), 69-81.

Oviatt, B., \& McDougall, P. (1994). Toward a theory of international new ventures. Journal of International Business Studies, 25(1), 45-64.

Porter, M. E. (1985). Competitive Advantage: Creating and Sustaining Superior Performance (Vol. 1 edition): Free Press.

Porter, M. E., \& Kramer, M. (2011). The Big Idea: Creating Shared Value. How to Reinvent Capitalism - and Unleash a Wave of Innovation and Growth. Harvard Business Review, 89(12), 62-77.

Quelch, J. A., \& Klein, L. (1996). The Internet and international marketing. Sloan Management Review, $37(3), 60-75$.

Rangan, S., \& Adner, R. (2001). Profits and the Internet: Seven misconceptions. MIT Sloan Management Review, 42(44-53).

Reuber, R. (2016). Multilingualism and the Internationalization of New Firms in Digital Markets. Paper presented at the AIB-UKI Conference, London.

Reuber, R., \& Fischer, E. (2011). International entrepreneurship in internet-enabled markets. Journal of Business Venturing, 26(6), 660-679.

Rezk, R., Srai, J. S., \& Williamson, P. J. (2016). The impact of product attributes and emerging technologies on firms' international configuration. Journal of International Business Studies, 47(5), 610-618.

Rialp, A., Rialp, J., \& Knight, G. A. (2005). The phenomenon of early internationalizing firms: what do we know after a decade (1993-2003) of scientific inquiry? International Business Review, 14(2), 147-166.

Rissanen, T., Ermolaeva, L., Ali, A., Torkkeli, L., \& Saarenketo, S. (2019). The role of home market context in business model change in internationalizing SMEs. European Business Review.

Rugman, A. (1980). A new theory of the multinational enterprise: Internationalization versus internalization. Columbia Journal of World Business, 15(1), 23-33.

Schu, M., Morschett, D., \& Swoboda, B. (2016). Internationalization Speed of Online Retailers: A Resource-Based Perspective on the Influence Factors. Management International Review, 56(5), 733-757.

Shaheer, N. A., \& Li, S. (2018). The CAGE around cyberspace? How digital innovations internationalize in a virtual world. Journal of Business Venturing.

Singh, N., \& Kundu, S. K. (2002). Explaining the Growth of E-Commerce Corporations (ECCs): An Extension and Application of the Eclectic Paradigm. Journal of International Business Studies, 33(4), 679-697.

Sinkovics, N., Sinkovics, R. R., \& Ruey-Jer, B. J. (2013). The internet as an alternative path to internationalization? International Marketing Review, 30(2), 130-155.

Stallkamp, M., \& Schotter, A. P. J. (2019). Platforms without borders? The international strategies of digital platform firms. Global Strategy Journal.

Styles, C., \& Genua, T. (2008). The rapid internationalization of high technology firms created through the commercialization of academic research. Journal of World Business, 43(2), 146-157.

Su, N. (2013). Internationalization Strategies of Chinese IT Service Suppliers. MIS Quarterly, 37(1), $175-200$.

Susarla, A., Anitesh, B., \& Whinston, A. B. (2003). Understanding the Service Component of Application Service Provision: An Empirical Analysis of Satisfaction with ASP Services. MIS Quarterly, 27(1), 91-123.

UNCTAD. (2017). World Investment Report. Investment and the digital economy Conference on trade and development. Geneva: United Nations. 
Vandermerwe, S., \& Rada, J. (1988). Servitization of business: Adding value by adding services. European Management Journal, 6(4), 314-324.

Watson, G., Weaven, S., Perkins, H., Sardana, D., \& Palmatier, R. (2018). International Market Entry Strategies: Relational, Digital, and Hybrid Approaches. Journal of International Marketing, 26(1), 30-60.

Webster, F. E., Jr. (1992). The Changing Role of Marketing in the Corporation. Journal of Marketing, 56(4), 1-17.

Wentrup, R. (2016). The online-offline balance: internationalization for Swedish online service providers. Journal of International Entrepreneurship, 14(4), 562-594.

Yamin, M., \& Sinkovics, R. R. (2006). Online internationalisation, psychic distance reduction and the virtuality trap. International Business Review, 15(4), 339-360.

Zaheer, S. (2002). The liability of foreignness, redux: a commentary. Journal of International Management, 8(3), 351-358.

Zhu, H., \& Qian, G. (2015). High-tech firms' international acquisition performance: The influence of host country property rights protection. International Business Review, 24(4), 556-566.

Ziyae, B., Sajadi, S., \& Mobaraki, M. (2014). The deployment and internationalization speed of ebusiness in the digital entrepreneurship era. Journal of Global Entrepreneurship Research, 4(1), 1-11.

Zou, H., Chen, X., \& Ghauri, P. (2010). Antecedents and consequences of new venture growth strategy: An empirical study in China. Asia Pacific Journal of Management, 27(3), 393-421.

Zucchella, A., Palamara, G., \& Denicolai, S. (2007). The drivers of the early internationalization of the firm. Journal of World Business, 42(3), 268-280. 
Table 1. Sources identified by the literature review.

\begin{tabular}{|c|c|c|c|}
\hline ID & $\begin{array}{r}\text { Ref. } \\
\end{array}$ & $\begin{array}{r}\text { Type of research } \\
\end{array}$ & Sample, if empirical \\
\hline 1 & (Brouthers et al., 2016) & $\begin{array}{l}\text { Empirical: Qualitative, semi-structured interviews, exploratory } \\
\text { case study }\end{array}$ & $\begin{array}{l}\text { Nine German companies (seven marketplaces, two } \\
\text { communities) }\end{array}$ \\
\hline 2 & (Zhu \& Qian, 2015) & Empirical: Quantitative, secondary data & $\begin{array}{l}1191 \text { international acquisitions (from } 49 \text { countries) } \\
\text { made by US acquirers (ITC industry) }\end{array}$ \\
\hline 3 & (L. Li et al., 2012) & Empirical: Quantitative, secondary data & 278 US SMTEs (ITC industry) \\
\hline 4 & (Mahnke \& Venzin, 2003) & Empirical: Qualitative, exploratory case study & One CS: eBay \\
\hline 5 & (Luo et al., 2005) & Empirical: Quantitative, secondary data & 93 US Internet companies \\
\hline 6 & (Crick \& Spence, 2005) & Empirical: Qualitative, semi-structured interviews & 12 in-depth interviews with UK high-tech SMEs \\
\hline 7 & (Campos et al., 2009) & $\begin{array}{l}\text { Empirical: Qualitative, semi-structured interviews, exploratory } \\
\text { case study }\end{array}$ & Six Mexican companies \\
\hline 8 & (Bell \& Loane, 2010) & Empirical: Qualitative, exploratory case study & Five Internet companies \\
\hline 9 & (Almor et al., 2014) & Empirical: Quantitative longitudinal study, secondary data & 57 Israeli technology-based companies \\
\hline 10 & (Kim, 2003) & Empirical: Qualitative, exploratory case study & $\begin{array}{l}\text { Case studies: Yahoo! Inc., AOL, Lycos, and } \\
\text { AltaVista }\end{array}$ \\
\hline 11 & (Hennart, 2014) & Conceptual: Literature review, case study & Three case studies \\
\hline 12 & (Reuber, 2016) & Empirical: Qualitative, case study & Seven eINVs \\
\hline 13 & (Wentrup, 2016) & $\begin{array}{l}\text { Empirical: Qualitative, semi-structured interviews, exploratory } \\
\text { case study }\end{array}$ & Three Swedish companies \\
\hline 14 & (Singh \& Kundu, 2002) & Conceptual: Case study & $\begin{array}{l}\text { Amazon.com, Yahoo.com, Landesend.com, } \\
\text { Cnet.com, AOL.com, Ebay.com, etc. }\end{array}$ \\
\hline 15 & (Mahadevan, 2000) & Conceptual: Case study & Amazon.com, AOL.com, Ebay.com, etc. \\
\hline 16 & (Hänninen et al., 2017) & $\begin{array}{l}\text { Empirical: Literature review, content analysis, qualitative case } \\
\text { study }\end{array}$ & $\begin{array}{l}\text { Alibaba Group, Amazon.com, eBay and Rakuten } \\
\text { Group }\end{array}$ \\
\hline 17 & (Susarla et al., 2003) & Empirical: Quantitative, questionnaires & 256 software and services companies \\
\hline
\end{tabular}




\begin{tabular}{|c|c|c|c|}
\hline 18 & (Su, 2013) & $\begin{array}{l}\text { Empirical: Qualitative, semi-structured, secondary data, } \\
\text { interviews, case studies }\end{array}$ & 13 China-based IT service companies \\
\hline 19 & (Ojala \& Tyrvainen, 2006) & $\begin{array}{l}\text { Empirical: Qualitative, secondary data, semi-structured open- } \\
\text { ended interviews, case studies }\end{array}$ & Eight Finnish software companies \\
\hline 20 & (Styles \& Genua, 2008) & $\begin{array}{l}\text { Empirical: Qualitative, personal interviews (observation, } \\
\text { documentation), secondary data, case studies }\end{array}$ & Four Australian high-tech companies \\
\hline 21 & (Juho \& Mainela, 2009) & $\begin{array}{l}\text { Empirical: Qualitative, longitudinal research, semi-structured } \\
\text { interviews, secondary data (observation), in-depth case study }\end{array}$ & Two Finish high-tech companies \\
\hline 22 & (Stallkamp \& Schotter, 2019) & $\begin{array}{l}\text { Empirical: Qualitative, interviews, secondary data, case studies, } \\
\text { conceptual }\end{array}$ & Nine platform companies (country n/a) \\
\hline 23 & (Javalgi et al., 2012) & Empirical: Qualitative, secondary data, in-depth case study & Three Indian companies \\
\hline 24 & (Luo \& Bu, 2016) & $\begin{array}{l}\text { Empirical: Quantitative, face-to-face interviews, standardized } \\
\text { questionnaires }\end{array}$ & 6236 companies from 27 emerging economies \\
\hline 25 & (Chen \& Kamal, 2016) & Empirical: Quantitative, survey & 22,000 US companies \\
\hline 26 & $\begin{array}{l}\text { (Rezk, Srai, \& Williamson, } \\
\text { 2016) }\end{array}$ & Empirical: Quantitative, questionnaire, interviews & $\begin{array}{l}96 \text { interviews with designers, engineers, industry } \\
\text { experts, and researchers from companies based in } \\
\text { Europe, US, China, Brazil, Mexico, and Egypt }\end{array}$ \\
\hline 27 & (Hagsten \& Kotnik, 2017) & Empirical: Quantitative & $\begin{array}{l}\text { Companies from } 12 \text { European countries (ESSLait } \\
\text { firm-level datasets) }\end{array}$ \\
\hline 28 & $\begin{array}{l}\text { (Watson, Weaven, Perkins, } \\
\text { Sardana, \& Palmatier, 2018) }\end{array}$ & Conceptual: Case studies & $\begin{array}{l}\text { Dubai Ports World, Michel's Patisserie Franchises, } \\
\text { eBay Small Businesses, Adobe SMEs, Embraer } \\
\text { Aircraft, Fleetguard Filters, Blackboard Educational, } \\
\text { Google SMEs }\end{array}$ \\
\hline 29 & (Shaheer \& Li, 2018) & $\begin{array}{l}\text { Empirical: Quantitative, longitudinal, cross country, secondary } \\
\text { data }\end{array}$ & 127 apps at Apple’s app store \\
\hline 30 & (Ojala, Evers, \& Rialp, 2018) & $\begin{array}{l}\text { Empirical: Qualitative, longitudinal single-case study, in-depth } \\
\text { case study, interviews, secondary data }\end{array}$ & G-cluster from Japan \\
\hline 31 & $\begin{array}{l}\text { (Martinez-Noya, Garcia-Canal, } \\
\text { \& Guillen, 2012) }\end{array}$ & $\begin{array}{l}\text { Empirical: Quantitative, multilanguage cross-country } \\
\text { questionnaire, interviews }\end{array}$ & $\begin{array}{l}182 \text { technology-intensive companies from the US and } \\
\text { European Union }\end{array}$ \\
\hline
\end{tabular}




\begin{tabular}{|c|c|c|c|}
\hline 32 & $\begin{array}{l}\text { (Caniëls, Lenaerts, } \quad \& \\
\text { Gelderman, 2015) }\end{array}$ & Empirical: Quantitative, questionnaire & 78 Belgian SMEs \\
\hline 33 & $\begin{array}{l}\text { (Ziyae, Sajadi, \& Mobaraki, } \\
\text { 2014) }\end{array}$ & Empirical: Quantitative, questionnaire & 135 Danish SMEs \\
\hline 34 & $\begin{array}{l}\text { (Gabrielsson \& Gabrielsson, } \\
\text { 2011) }\end{array}$ & $\begin{array}{l}\text { Empirical: Qualitative, case study, interview, semi-structured } \\
\text { questionnaire, secondary literature }\end{array}$ & 35 Finnish SMEs \\
\hline 35 & (Ifinedo, 2011) & Empirical: Quantitative, questionnaire & 214 Canadian SMEs \\
\hline
\end{tabular}

Table 2. Overview of metrics from the sources identified in the literature review.

\begin{tabular}{|c|c|c|c|c|c|c|}
\hline ID & $\begin{array}{c}\text { Terms used to } \\
\text { define } \\
\text { digitalized/ing } \\
\text { companies }\end{array}$ & Definitions & DOD metrics & DOI metrics & DOI (range) & Type of companies \\
\hline 1 & $\begin{array}{l}\text { ibusiness/e- } \\
\text { business } \\
\text { companies }\end{array}$ & $\begin{array}{l}\text { Any firm operating online } \\
\text { that provides its } \\
\text { products/services to } \\
\text { customers using the Internet } \\
\text { and other computer-based } \\
\text { information system } \\
\text { technologies. }\end{array}$ & Online platform & $\begin{array}{l}\text { Sales; number of users in } \\
\text { different markets, networks }\end{array}$ & $\begin{array}{l}\text { Number of foreign markets } \\
(1-150)\end{array}$ & $\begin{array}{l}\text { Web-based (products and } \\
\text { services) }\end{array}$ \\
\hline 2 & $\begin{array}{l}\text { High-tech } \\
\text { companies }\end{array}$ & $\mathrm{n} / \mathrm{a}$ & High-tech industry & $\begin{array}{l}\text { Entry modes: Acquisitions; } \\
\text { post-acquisition performance }\end{array}$ & $>1$ foreign countries & IT (products and services) \\
\hline 3 & $\begin{array}{l}\text { Small- and } \\
\text { medium-sized } \\
\text { technology-based } \\
\text { enterprises }\end{array}$ & $\begin{array}{l}\text { Enterprises that employ } \\
\text { fewer than } 500 \text { people and } \\
\text { have R\&D intensity }>3.5 \% \text {. }\end{array}$ & High-tech industry & $\begin{array}{l}\text { International diversification: } \\
\text { Geographic spread and } \\
\text { concentration; product } \\
\text { diversification: Related and } \\
\text { unrelated diversification }\end{array}$ & $>1$ foreign countries & $\begin{array}{l}\text { High-tech } \\
\text { (products and services) }\end{array}$ \\
\hline
\end{tabular}




\begin{tabular}{|c|c|c|c|c|c|c|}
\hline 4 & $\begin{array}{l}\text { Digital } \\
\text { information } \\
\text { goods providers }\end{array}$ & $\begin{array}{l}\text { Companies deriving most } \\
\text { income from one or more } \\
\text { Internet-related activities. }\end{array}$ & $\begin{array}{l}\text { Internet technology: } \\
\text { Digital information goods }\end{array}$ & $\begin{array}{l}\text { Entry mode (in a single } \\
\text { foreign market) and entry } \\
\text { patterns (across foreign } \\
\text { markets), networks }\end{array}$ & International company & $\begin{array}{l}\text { Web-based } \\
\text { (services) }\end{array}$ \\
\hline 5 & $\begin{array}{l}\text { e-commerce } \\
\text { companies }\end{array}$ & $\begin{array}{l}\text { Companies whose business } \\
\text { activities are entirely } \\
\text { Internet-based. }\end{array}$ & $\begin{array}{l}\text { Online } \\
\text { platform/eShop/marketpla } \\
\text { ce }\end{array}$ & $\begin{array}{l}\text { Speedy foreign market entry, } \\
\text { sequence, coverage }\end{array}$ & $>1$ foreign countries & $\begin{array}{l}\text { Web-based (products and } \\
\text { services) }\end{array}$ \\
\hline 6 & High-tech SMEs & $\begin{array}{l}\text { Generally, small- and } \\
\text { medium-sized companies } \\
\text { with advanced tech } \\
\text { knowledge and capabilities, } \\
\text { an educated workforce, and } \\
\text { the ability to adapt quickly to } \\
\text { fast-changing environments. }\end{array}$ & $\begin{array}{l}\text { Advanced tech knowledge } \\
\text { and capabilities }\end{array}$ & $\begin{array}{l}\text { Speed of } \\
\text { internationalization, years } \\
\text { from start-up; sales volume } \\
\text { and growth, profitability and } \\
\text { market share; market } \\
\text { strategy, networking }\end{array}$ & $>1$ foreign countries & $\begin{array}{l}\text { High-tech } \\
\text { (products and services) }\end{array}$ \\
\hline 7 & $\begin{array}{l}\text { New technology- } \\
\text { based companies }\end{array}$ & $\begin{array}{l}\text { Independent companies } 10 \\
\text { years old or younger, and } \\
\text { their operations are based on } \\
\text { exploiting the firm's } \\
\text { technological resources, } \\
\text { meaning as the firm actively } \\
\text { develops, it produces and/or } \\
\text { commercializes technology. }\end{array}$ & $\begin{array}{l}\text { Technology companies } \\
\text { (from Technology-Based } \\
\text { Business Incubator } \\
\text { Network) }\end{array}$ & $\begin{array}{l}\text { Relationship between } \\
\text { technology strategy and } \\
\text { performance }\end{array}$ & $\mathrm{n} / \mathrm{a}$ & $\begin{array}{l}\text { Technology-based } \\
\text { (products and services) }\end{array}$ \\
\hline 8 & $\begin{array}{l}\text { "New-wave" } \\
\text { global companies }\end{array}$ & $\begin{array}{l}\text { Entrepreneurial companies } \\
\text { that "pursue rapid and } \\
\text { dedicated } \\
\text { internationalization from } \\
\text { inception or shortly } \\
\text { thereafter" (Oviatt \& } \\
\text { McDougall, 1994, p. 49). } \\
\text { The Internet is a key driver } \\
\text { of business development and } \\
\text { speedy internationalization. }\end{array}$ & Internet-based companies & $\begin{array}{l}\text { Rapid internationalization } \\
\text { based on close collaboration } \\
\text { with other companies and } \\
\text { co-creation with customers, } \\
\text { networking }\end{array}$ & $>1$ foreign countries & $\begin{array}{l}\text { Web-based (products and } \\
\text { services) }\end{array}$ \\
\hline
\end{tabular}




\begin{tabular}{|c|c|c|c|c|c|c|}
\hline 9 & $\begin{array}{l}\text { Maturing } \\
\text { technology- } \\
\text { based, born- } \\
\text { global companies }\end{array}$ & $\begin{array}{l}\text { Often characterized by } \\
\text { proprietary technologies and } \\
\text { innovations. }\end{array}$ & $\begin{array}{l}\text { Information and } \\
\text { communication } \\
\text { technology (ICT) sector: } \\
\text { software, hardware, } \\
\text { electronics industries }\end{array}$ & $\begin{array}{l}\text { Entry modes: Mergers and } \\
\text { acquisitions }\end{array}$ & $>1$ foreign countries & $\begin{array}{l}\text { High-tech } \\
\text { (products and services) }\end{array}$ \\
\hline 10 & Internet portals & Internet companies. & Online portal & $\begin{array}{l}\text { Entry modes, speed, } \\
\text { internationalization strategy }\end{array}$ & $>1$ foreign countries & $\begin{array}{l}\text { Web-based } \\
\text { (services) }\end{array}$ \\
\hline 11 & $\begin{array}{l}\text { Accidental } \\
\text { internationalists }\end{array}$ & $\begin{array}{l}\text { INVs/BGs possess superior } \\
\text { technological resources } \\
\text { which they exploit by selling } \\
\text { knowledge-intensive } \\
\text { products. } \\
\text { Acquiring foreign customers } \\
\text { is for INVs/BGs no different } \\
\text { than acquiring domestic } \\
\text { ones. In that sense, } \\
\text { INVs/BGs are accidental } \\
\text { internationalists. }\end{array}$ & $\begin{array}{l}\text { Technology company } \\
\text { (Atlassian) }\end{array}$ & $\begin{array}{l}\text { Speed, knowledge, business } \\
\text { model }\end{array}$ & $>1$ foreign countries & $\begin{array}{l}\text { Web-based } \\
\text { (products and services) }\end{array}$ \\
\hline 12 & eINV & $\begin{array}{l}\text { A venture whose business } \\
\text { model is based on a digital } \\
\text { platform and that seeks, from } \\
\text { inception, to derive } \\
\text { significant competitive } \\
\text { advantage from international } \\
\text { growth. }\end{array}$ & Digital platform & $\begin{array}{l}\text { Language boundaries, } \\
\text { adaptation, standardization }\end{array}$ & $>1$ foreign countries & $\begin{array}{l}\text { Web-based } \\
\text { (services) }\end{array}$ \\
\hline 13 & $\begin{array}{l}\text { Online service } \\
\text { providers }\end{array}$ & $\begin{array}{l}\text { Any company, organization, } \\
\text { or group providing an online } \\
\text { service. }\end{array}$ & $\begin{array}{l}\text { Web and mobile } \\
\text { technology companies }\end{array}$ & $\begin{array}{l}\text { Online-offline balance: } \\
\text { Speed, geography, mode of } \\
\text { entry }\end{array}$ & $>1$ foreign countries & $\begin{array}{l}\text { Web-based } \\
\text { (services) }\end{array}$ \\
\hline 14 & $\begin{array}{l}\text { e-commerce } \\
\text { corporations }\end{array}$ & $\begin{array}{l}\text { Organizations engaged from } \\
\text { inception in electronic } \\
\text { commerce; derive significant }\end{array}$ & $\begin{array}{l}\text { Online } \\
\text { platform/eShop/marketpla } \\
\text { ce }\end{array}$ & Growth, networks & $>1$ foreign countries & $\begin{array}{l}\text { Web-based } \\
\text { (services) }\end{array}$ \\
\hline
\end{tabular}




\begin{tabular}{|c|c|c|c|c|c|c|}
\hline & & $\begin{array}{l}\text { competitive advantage from } \\
\text { the use of network resources } \\
\text { resident in virtual networks } \\
\text { of commercial collaborative } \\
\text { alliances. }\end{array}$ & & & & \\
\hline 15 & $\begin{array}{l}\text { Internet-based } \\
\text { business, } \\
\text { Internet-based e- } \\
\text { commerce, and } \\
\text { business over the } \\
\text { net }\end{array}$ & $\begin{array}{l}\text { Organizations that conduct } \\
\text { commercial transactions with } \\
\text { business partners and buyers } \\
\text { over the net (exclusively or } \\
\text { in addition to brick-and- } \\
\text { mortar operations). }\end{array}$ & $\begin{array}{l}\text { Online } \\
\text { platform/portal/eShop/mar } \\
\text { ketplace }\end{array}$ & Business model & $>1$ foreign countries & $\begin{array}{l}\text { Web-based } \\
\text { (product and services) }\end{array}$ \\
\hline 16 & $\begin{array}{l}\text { Digital multi- } \\
\text { sided platforms }\end{array}$ & $\begin{array}{l}\text { Facilitate interaction and the } \\
\text { seamless exchange of } \\
\text { products between consumers } \\
\text { and independent suppliers } \\
\text { through a multi-sided digital } \\
\text { platform-mediated } \\
\text { marketplace. }\end{array}$ & $\begin{array}{l}\text { Online } \\
\text { platform/marketplace }\end{array}$ & Business model & $>1$ foreign countries & $\begin{array}{l}\text { Web-based } \\
\text { (services) }\end{array}$ \\
\hline 17 & $\begin{array}{l}\text { Application } \\
\text { service providers } \\
\text { (ASPs) }\end{array}$ & $\begin{array}{l}\text { Company that provides } \\
\text { access to remotely hosted IT } \\
\text { applications over a wide area } \\
\text { network (WAN),virtual } \\
\text { private network (VPN), or } \\
\text { the Internet. }\end{array}$ & $\begin{array}{l}\text { Online } \\
\text { platform/marketplace }\end{array}$ & Business model & $>1$ foreign countries & $\begin{array}{l}\text { Web-based } \\
\text { (services) }\end{array}$ \\
\hline 18 & $\begin{array}{l}\text { IT service } \\
\text { suppliers }\end{array}$ & $\mathrm{n} / \mathrm{a}$ & Software solutions & $\begin{array}{l}\text { Business strategy: Time to } \\
\text { internationalize, entry modes }\end{array}$ & $>1$ foreign countries & $\begin{array}{l}\text { Software } \\
\text { (products and services) }\end{array}$ \\
\hline 19 & $\begin{array}{l}\text { Software } \\
\text { companies }\end{array}$ & $\mathrm{n} / \mathrm{a}$ & Software solutions & $\begin{array}{l}\text { Variation of business } \\
\text { models, entry modes }\end{array}$ & $>1$ foreign countries & $\begin{array}{l}\text { Software } \\
\text { (products and services) }\end{array}$ \\
\hline 20 & $\begin{array}{l}\text { High-technology } \\
\text { companies }\end{array}$ & $\mathrm{n} / \mathrm{a}$ & $\begin{array}{l}\text { Software and hardware } \\
\text { solutions }\end{array}$ & $\begin{array}{l}\text { Networks, entrepreneurial } \\
\text { orientation }\end{array}$ & $>1$ foreign countries & $\begin{array}{l}\text { High-tech (products and } \\
\text { services) }\end{array}$ \\
\hline
\end{tabular}




\begin{tabular}{|c|c|c|c|c|c|c|}
\hline 21 & $\begin{array}{l}\text { High-tech } \\
\text { companies }\end{array}$ & $\mathrm{n} / \mathrm{a}$ & $\begin{array}{l}\text { Software and hardware } \\
\text { solutions }\end{array}$ & $\begin{array}{l}\text { Entry modes (external } \\
\text { facilitation), networks }\end{array}$ & $>1$ foreign countries & $\begin{array}{l}\text { High-tech (products and } \\
\text { services) }\end{array}$ \\
\hline 22 & $\begin{array}{l}\text { Digital platform } \\
\text { companies }\end{array}$ & $\begin{array}{l}\text { Companies with business } \\
\text { models based on digital } \\
\text { platforms. }\end{array}$ & $\begin{array}{l}\text { Online } \\
\text { platform/marketplace }\end{array}$ & $\begin{array}{l}\text { Business model, networks, } \\
\text { entry modes, market } \\
\text { selection }\end{array}$ & $>1$ foreign countries & $\begin{array}{l}\text { Web-based } \\
\text { (services) }\end{array}$ \\
\hline 23 & $\begin{array}{l}\text { Internet-enabled } \\
\text { SMEs }\end{array}$ & $\begin{array}{l}\text { Companies with business } \\
\text { models based on Internet } \\
\text { technologies. }\end{array}$ & $\begin{array}{l}\text { Online } \\
\text { platform/marketplace }\end{array}$ & $\begin{array}{l}\text { Business model, decision- } \\
\text { making }\end{array}$ & $>1$ foreign countries & $\begin{array}{l}\text { Web-based } \\
\text { (services) }\end{array}$ \\
\hline 24 & $\begin{array}{l}\text { Emerging } \\
\text { economy } \\
\text { enterprises }\end{array}$ & $\mathrm{n} / \mathrm{a}$ & ICT resources/assets & Export sales, national sales & $>1$ foreign countries & Products and services \\
\hline 25 & $\begin{array}{l}\text { Multinational } \\
\text { firm }\end{array}$ & $\mathrm{n} / \mathrm{a}$ & $\begin{array}{l}\text { ICT adoption (e.g. } \\
\text { Internet-enabled network } \\
\text { technology, e-commerce } \\
\text { apps) }\end{array}$ & International trade & $>1$ foreign countries & Manufacturing-based \\
\hline 26 & $\begin{array}{l}\text { Multinational } \\
\text { firm }\end{array}$ & $\mathrm{n} / \mathrm{a}$ & $\begin{array}{l}\text { Product attributes (tier } \\
\text { structure, value density, } \\
\text { knowledge tacitness and } \\
\text { embeddedness, product } \\
\text { modularity) }\end{array}$ & $\begin{array}{l}\text { International configuration } \\
\text { of value chain (inward) }\end{array}$ & $>1$ foreign countries & Manufacturing-based \\
\hline 27 & SMEs & $\mathrm{n} / \mathrm{a}$ & $\begin{array}{l}\text { ICT usage (website, } \\
\text { online sales, ICT-schooled } \\
\text { employees) }\end{array}$ & $\begin{array}{l}\text { Export performance (export } \\
\text { activities, foreign ownership) }\end{array}$ & $>1$ foreign countries & Manufacturing and services \\
\hline 28 & $\mathrm{n} / \mathrm{a}$ & $\mathrm{n} / \mathrm{a}$ & $\begin{array}{l}\text { e-commerce, digital } \\
\text { delivery, SaaS, logistic } \\
\text { and communication } \\
\text { technology infrastructure }\end{array}$ & Entry modes, networks & $>1$ foreign countries & Manufacturing and services \\
\hline 29 & Start-ups & $\mathrm{n} / \mathrm{a}$ & Mobile apps & International penetration & $>1$ foreign countries & Services \\
\hline 30 & $\begin{array}{l}\text { Digital platform } \\
\text { providers/digital- } \\
\text { based INVs }\end{array}$ & $\begin{array}{l}\text { Digital platforms are defined } \\
\text { as " } a \text { shared, common set of } \\
\text { services and architecture } \\
\text { that serves to host }\end{array}$ & Online platform & Network, entry modes & $>1$ foreign countries & Services \\
\hline
\end{tabular}




\begin{tabular}{|c|c|c|c|c|c|c|}
\hline & & $\begin{array}{l}\text { complementary offerings" } \\
\text { (Nambisan, 2017, p. 1032) }\end{array}$ & & & & \\
\hline 31 & $\begin{array}{l}\text { Technology- } \\
\text { intensive } \\
\text { companies }\end{array}$ & $\begin{array}{l}\text { Coordinate and integrate } \\
\text { distributed activities along } \\
\text { their value chains; explore } \\
\text { and exploit emerging } \\
\text { technologies }\end{array}$ & $\begin{array}{l}\text { e-commerce, digital } \\
\text { delivery, SaaS, logistic } \\
\text { and communication } \\
\text { technology infrastructure }\end{array}$ & Outsourcing (R\&D) & $>1$ foreign countries & Manufacturing and services \\
\hline 32 & SMEs & $\mathrm{n} / \mathrm{a}$ & $\begin{array}{l}\text { Internet usage and } \\
\text { technology }\end{array}$ & Market orientation & $>1$ foreign countries & Manufacturing and services \\
\hline 33 & $\begin{array}{l}\text { Electronic } \\
\text { businesses }\end{array}$ & $\mathrm{n} / \mathrm{a}$ & $\begin{array}{l}\text { Internet-based } \\
\text { technologies }\end{array}$ & $\begin{array}{l}\text { Speed of foreign market } \\
\text { entry }\end{array}$ & $>1$ foreign countries & Manufacturing and services \\
\hline 34 & Born-global firms & $\begin{array}{l}\text { A firm that "from inception, } \\
\text { seeks to derive significant } \\
\text { competitive advantage from } \\
\text { the use of resources and the } \\
\text { sales of outputs in multiple } \\
\text { countries" (Oviatt \& } \\
\text { McDougall, 1994, p. 49) }\end{array}$ & $\begin{array}{l}\text { Internet-based channels, } \\
\text { technology infrastructure, } \\
\text { brick-and-mortar }\end{array}$ & $\begin{array}{l}\text { Entry modes, international } \\
\text { sales }\end{array}$ & $>1$ foreign countries & Manufacturing and services \\
\hline 35 & SMEs & $\mathrm{n} / \mathrm{a}$ & $\begin{array}{l}\text { Use of Internet and e- } \\
\text { business technologies }\end{array}$ & International sales & $>1$ foreign countries & Manufacturing and services \\
\hline
\end{tabular}

